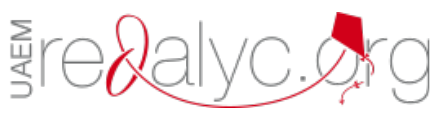

Centro Sur

ISSN: $2600-5743$

compasacademico@icloud.com

Grupo Compás

Ecuador

\title{
Implementing backward design to improve students' academic performance in EFL classes
}

\author{
Ontaneda Rea, Mónica; Sánchez Román, Jorge Luis \\ Implementing backward design to improve students' academic performance in EFL classes \\ Centro Sur, vol. 2, núm. 2, 2018 \\ Grupo Compás, Ecuador \\ Disponible en: http://www.redalyc.org/articulo.oa?id=588861693003
}

Esta obra está bajo una Licencia Creative Commons Atribución-NoComercial-SinDerivar 4.0 Internacional. 


\section{Implementing backward design to improve students' academic performance in EFL classes}

\author{
Implementación de diseño hacia atrás para mejorar \\ rendimiento académico de los estudiantes en las clases de EFL \\ Mónica Ontaneda Rea montaneda@itsvr.edu.ec \\ Instituto Superior Vicente Rocafuerte, Ecuador \\ http://orcid.org/0000-0002-2304-911X \\ Jorge Luis Sánchez Román jsanchez@gmail.com \\ Institución Universitaria Centro de Estudios Superiores Maria Goretti, \\ Ecuador \\ http://orcid.org/0000-0003-0505-1993
}

Centro Sur, vol. 2, núm. 2, 2018

Grupo Compás, Ecuador

Recepción: 03 Enero 2017 Aprobación: 22 Agosto 2018

Redalyc: http://www.redalyc.org/ articulo.oa?id $=588861693003$
Resumen: Este estudio se basa en la implementación de un diseño hacia atrás para mejorar la evaluación académica de los estudiantes, de modo que los estudiantes de secundaria pública puedan participar en contextos significativos donde muestran lo que aprendieron al final de un período de clase. Teniendo en cuenta, el diseño hacia atrás es una gran herramienta para aplicar en las escuelas secundarias públicas, donde la mayoría de las clases están centradas en los libros de texto, lo que provoca la frustración de los estudiantes debido a la falta de conocimiento del inglés de las escuelas. Hay una alta tasa de estudiantes que fallan en los cursos porque los estudiantes se colocan en niveles de inglés a los que no pertenecen o provienen de otras instituciones donde no aprendieron inglés. El diseño hacia atrás permite a los maestros ser creativos y usar habilidades y metodologías de acuerdo con las necesidades de los estudiantes y ser muy reflexivos en la forma de diseñarlo. En este estudio, pairedT_Test se aplica para comparar puntajes del mismo nivel, pero utilizando diferentes formas de prueba. En conclusión, el grupo experimental (G2), en el que se aplicó el diseño hacia atrás, obtuvo mejores resultados que el grupo controlado (G1), que no lo aplicó. En este caso, la variable independiente que significa y puntajes es alta. Los resultados muestran que el diseño hacia atrás es muy significativo no solo para los estudiantes, sino también para los maestros.

Palabras clave: diseño hacia atrás, resultados deseados, planes de acción.

Abstract: This study is based on implementing backward design to improve students' academic assessment, so public high school students can take part of meaningful contexts where they show what they learned at the end of a class term. Taking in consideration, backward design is a great tool to be applied for public high schools where most of the classes are textbooks centered, provoking students' frustration due to the lack of English knowledge from schools. There is a high rate of students failing courses because students are placed in English levels where they do not belong to or they come from other institutions where they did not learn English. Backward design lets teachers be creative and use skills and methodologies according to students' needs and be very reflexive in the way of designing it. In this study, pairedT_Test is applied to compare scores from the same level, but using different ways of testing. In conclusion, the experimental group (G2), in which backward design was applied, got better results than the controlled group (G1), who did not apply it. In this case the independent variable which mean and scores are high. Results show backward design is very meaningful not only for students, but also for teachers. It is true that running appropriate action plans, selecting the best resources and conducting a final assessment through a performance task, gave the opportunity for students to gain more confidence on the language and apply it in a real context.

Keywords: backward design, desired results, action plans. 


\section{INTRODUCTION}

In public high school, the curriculum plan is embedded in the teachers' guide textbooks, and many public teachers follow them as bibles whose desired results are completely different from what they really expected because of omitting students' needs and they do not design them. Besides, when observing teachers' performance in class with their own students, many of them stayed in the acquisition and meaning making stages, but none of them could show any transfer goal where students apply their knowledge into meaningful contexts also known as performance tasks as types of assessment.

Thanks to this mastery program and the guide of it, task performances as summative assessments, were conducted with students from 1 st baccalaureate in an easy way, where the assessing week was extended and colleagues were the judges who graded students' performance through rubrics where desired results were great and authorities were happy with them. Colleagues also learned from this experience, too. So that, backward design is very helpful and let us be architects, designers, creators of what it is expected to see on students.

When designing backward design, teachers become designers, creators of their effective ways based on English Standards to build their own transfer goal. Besides, the backward design has the formative and summative assessments that teachers should develop according to what students need to learn and understand. Like professional designers in education, backward design must be mindful to their audience, whose purpose is strongly student-centered and if students are our primary clients by giving them the effectiveness of curriculum assessment, then instructional design is determined by students' achievement of desired learning.

Assessment is a natural on-going important component of the teaching process. It encompasses the general process of collecting, synthesizing and interpreting information. stated "An education system is incomplete without assessment". The National Policy on Education, defines assessment as a continuous planned process of gathering information about performance of learners, measured against specific learning objectives. This indicates that the information about the performance of learners must be measured against specific learning objectives identified by the teachers.

Wiggins (2012), states that standardized testing like the ones commonly apply in schools do not predict future performance or success, it just predicts freshman grade point average in their first semester and there is plenty of studies that grades in college do not correlate with later success. So, backward design has a performance task, where students put in practice what they learnt through a meaningful context.

"Current knowledge" implies that what a student knows is always changing so that judgment can be made about student achievement through comparisons over a period of time. According to Stiggens, Assessment at any level of education aim at transforming the schools 
into one which creates the best conditions for learning, encourages best practices and inspires creativity and innovation. Assessment provides essential information on learners' learning needs, monitoring of students' progress and for helping students to structure their learning.

Thus, how stakeholders perceive assessment is crucial in determining teachers 'effectiveness in the utilization of information from assessment for formative and diagnostic purposes in which backward design is very helpful to make a real change in education. My recent course grades show it, compared to the ones belong to the afternoon period where there is another teacher using the conventional method brought by textbooks.

William, (2003). Professor of Educational Assessment at King's College \& London says that current educational systems provide assessments which are not trustful and reliable, causing a narrowing of the curriculum due to tests assess particular aspects of the national curriculum in a distinctive way. For instance, the national curriculum for mathematics let students collect and interpret discrete and continuous data, which are not possible to assess adequately in a given test.

The most important feature of the assessment system is the evaluative function of the assessment based on the possibility to assess a greater proportion of the domain of interest. More precisely, creating a situation in which teachers are happy with the improvement of students' scores and performance on the whole domain. So, to what extend does backward design help teachers to assess students properly in EFL classes?

The following literature review supports a backward design to improve student's academic assessment in EFL classes. The literature review focused on the five themes related to the title proposal where the main information is summarized after an analysis of participants' experiences. Themes are more specifically, theme one "backward design for forward action" (McTighe \& Thomas, 2003), theme two, "what backward design is" (Wiggins \& McTighe, 1998), theme three, "a planning tool for incorporating backward design, active learning, and authentic assessment in the college classroom" ( Reynolds, \& Kearns, 2017), theme 4, "designing for learning" (Wiggins, 2012) and theme 5, "collaborative practice" (p. 105).

Backward design for forward action has three main stages that contribute to curriculum planning, and ensure made decisions. For backward design to work, teachers should identify desired results, analyze multiple sources of data, and determine appropriate action plans (McTighe \& Thomas, 2003). All of them benefit students' learning process for example: identify desired results, educators uncover the key ideas within the content and then develop essential questions that explore these ideas. Every school effort is to improve student learning of important content, not just to raise standardized test scores

Besides, analyzing multiple sources embedded in the content standards, which lead to improve school's initiative while seeking answers for students to learn specific facts in the context of exploring them. When developing the action plan is necessary to identify learning goals and analyzed assessment data, so teachers can help students through learning 
experiences to understand key concepts. Also, school improvement teams can generate action plans focused on obtaining desired results.

In the backward design, teachers are designers of the curriculum and learning experiences to meet specific objectives and at the same time, they are the designers of assessments to determine if goals have been achieved. Besides, backward design teachers start with the desired results and then deriving the curriculum from the evidence of learning (performances) that equip students to perform and their learning experiences are also enriched through informal check for understanding, observation/ dialogue, quiz/test and academic prompts (Wiggins \& McTighe, 1998).

When planning a tool for incorporating backward design, active learning, it inspires a lesson planner who restructures college course periods to be more active including learner-centered activities to fulfill objectives that are aligned with course goals. The planner carried out the application of backward design in a biology class where students shared perception of classroom structure with the teacher and used classroom time before and after implementation. In addition, the backward design planner prioritized content given to students, who could better manage time in and out of the classroom, improved lecture preparation experiences and involved students with more frequent feedback on student comprehension as benefits of its implementation (Reynolds \& Kearns, 2017)

Wiggins (2012), stated the following for designing for learning:

"Transfer is the aim of any education. Given that there is too much for anyone to learn; given that unpredictability is inevitable; given that being flexible and adaptive with one's repertoire is key to any future success, it stands to reason that we should focus our 'backward-design' efforts on the goal of transfer, regardless of what and who we teach" (p. 18).

Besides Jones' 2010 study (as cited in Patte, 2009) found the following:

"Collaboration with peers and families provides growth opportunities for teachers. Stated that effective home-school collaboration led to highly successful academic outcomes for students. Educators working with the families lessened the gap that exists between schools and homes often. Jones suggested the following characteristics identified in schools established effective collaborative partnerships with families "open communication, open-door policies, active parent associations and advisory councils, parent volunteers, an inclusive school culture, and, shared responsibility for success and failures" (p. 1) of their students. Collaboration contributed value for the educator and families" (p. 105).

\section{MATERIALS AND METHODS}

The instruments were:

- Observation

- Observers' surveys \& students 'surveys

- Pairedt_Test comparing scores from groups of the same level.

All of them let describe the evolution of this research work and know the way backward design help students to improve grades and academic 
performances for summative tests which is conducted in one course of 1 st baccalaureate from the morning period and compared to the one in the afternoon as controlled group using conventional testing methods. Besides, this study is essential to the success of implementing backward design in real-world classrooms instead of testing students on grammar and vocabulary items from lessons taken from textbooks.

One hypothesis was generated to guide this study: There is a strong difference in students' grades results from the morning period, applying backward design whose average is 8.30 , and the one in the afternoon period, whose average is 5.31, using the conventional curriculum plan. Both of them are from the same level (1st. Baccalaureate),

Sample or participants

The sample consisted 72 students (36 students from controlled group and 36 students from experiment group), all of them from the same level and who belong to the same High School in Guayaquil, Ecuador.

\section{RESULTS}

To what extend does backward design help teachers to assess students properly in EFL classes?

\section{TABLE 1}

Paired samples statistics

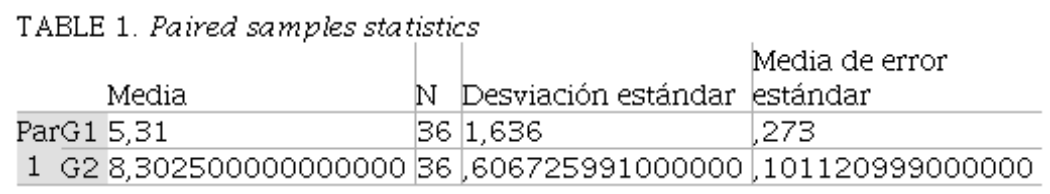

The authors

According to the both group variables, the mean of G1 is 5,31 and the mean of $\mathrm{G} 2$ is 8,30 , which indicate there is a significant difference between them and the average standard deviation is 1,02 which means results are great. In other words, G2 who received the treatment got very good results compared to G1 who do not receive the treatment and got low scores.

\section{TABLE 2}

Paired samples correlations

TABLE 2. Paired samples correlations
\begin{tabular}{llll|l} 
Correlación & Sig. \\
\hline $\begin{array}{l}\text { Par } \\
\text { G } 1 \& 3\end{array}$ & 36 &,- 280 &, 098 \\
1 & $G 2$ & & & \\
\hline
\end{tabular}


The correlation here is significant even though it is negative and the significance error is (.1)

The differences in both means are 2,99 and the standard deviation is 1,89 from different scores of 36 students per group. Standard deviation error associated with the mean is, 32 then $t$-value is $-9,49$ with a degree of freedom of 35 and a significance of ,000, which is less than the criteria (.05), and it is extremely significance.

\section{DISCUSSION}

Applying backward design is very significant in comparison to other teachers who follow the national curriculum plan given in their teachers' guide, where there is no reflection on the three different stages that backward design provides such as starting with desired results, analyze multiple sources of data and determine an appropriate action plan. In the institution, there are many students who fail in English language and it is sometimes hated by them due to lack of stages involved in the national curriculum plan offered to teachers. However, looking for appropriate action plans based on students' needs and assessing them properly through performance tasks as summative tests show how a transfer goal is accomplished.

In conclusion, the experimental group (G2), in which backward design was applied, got better results than the controlled group (G1), who did not apply it. In this case the independent variable which mean and scores are high. Results show backward design is very meaningful not only for students also for teachers, too.

In the last question why backward design determine appropriate action plans to gain more knowledge in EFL classes, it is true that running appropriate action plans, selecting the best resources and conducting a final assessment through a performance task, gave the opportunity to students to gain more confidence on the language and apply it in a real context.

\section{Referencias}

Lehman, C. L. (2017). Multicultural Competence: A Literature Review Supporting Focused Training for Preservice Teachers Teaching Diverse Students. Journal of Education and Practice, 8(10), 109-116.

McTighe, J., \& Thomas, R. S. (2003). Backward design for forward action. Educational Leadership, 60(5), 52-55.

Patte, M. M. (2011). Examining Preservice Teacher Knowledge and Competencies in Establishing Family-School Partnerships. School Community Journal, 21(2), 143-159.

Reynolds, H. L., \& Kearns, K. D. (2017). A planning tool for incorporating backward design, active learning, and authentic assessment in the college classroom. College Teaching, 65(1), 17-27. 
Wiggins, G. (11 de enero de 2012).Transfer as the Point of Education. Retrieved from https://grantwiggins.wordpress.com/2012/01/11/transfer-as-thepoint-of-education/

Wiggins, G., \& McTighe, J. (1998). What is backward design?. Understanding by design, 1(1), 7-19.

Wiliam, D. (2003). National curriculum assessment: how to make it better. Research Papers in Education, 18(2), 129-136. 